\title{
An Empirical Study of the Economic Impact of the MICE Industry in China Using Interregional Input-output Models
}

\author{
Li Tiecheng ${ }^{1}$, Liu $\mathrm{Li}^{2}$, Wu Namei ${ }^{1}$ \\ ${ }^{1}$ South China Business College, Guangdong University of Foreign Studies, Guangzhou, China \\ ${ }^{2}$ International Economics and Trade College, Guangdong University of Foreign Studies, Guangzhou, China
}

Email address:

gdlitc@163.com (Li Tiecheng), gdlitc@163.com (Liu Li), nameiwu@qq.com (Wu Namei)

\section{To cite this article:}

Li Tiecheng, Liu Li, Wu Namei. An Empirical Study of the Economic Impact of the MICE Industry in China Using Interregional Input-output Models. American Journal of Management Science and Engineering. Vol. 3, No. 5, 2018, pp. 44-52. doi: 10.11648/j.ajmse.20180305.12

Received: September 29, 2018; Accepted: October 16, 2018; Published: November 1, 2018

\begin{abstract}
In the field of event activities, the study on the economic impact of MICE is relatively weak compared to sports activities. How to integrate all the industries and regions related to the MICE to avoid distortion and leakage is one of the difficulties in the study of the economy impact of the MICE. This study is the first time to use the interregional input-output model (IRI0) to calculate the intraregional and interregional influence power of the MICE industry in 30 provinces by merging the 12 industrial sectors that related to MICE. Taking the Canton Fair as a case, we have an empirical analysis of the indirect economic impact of the MICE. The research results show that China's MICE industry has a strong pulling effect on the national economy, and almost all regions will have a mutual diffusion effect. As for total output, the influence power of the MICE industry shows obvious differences in the East Coast and Midwest. There is still room for development in China's MICE industry. Case studies show that the indirect economic impact of the 104th Canton Fair is about 16.243 billion yuan (the highest proportion in Guangdong, 35.09\%), the ratio of direct and indirect impact is 1:2.94, five industrial sectors such as wholesale and retail trade affected by the Canton Fair, the total proportion is $77 \%$.
\end{abstract}

Keywords: MICE Industry, China, Indirect Economic Impact, Interregional Input-Output Model (IRIO), Canton Fair

\section{Introduction}

The meetings, incentive travel, conventions, and exhibitions (MICE) industry is considered to be one of the industries with strong economic pulling power, which has been developed rapidly in China in recent years. The landmark events such as the 2008 Beijing Olympic Games, the 2010 Shanghai World Expo, the 2010 Guangzhou Asian Games and the 2011 Shenzhen World Universiade, have played a great role in promoting MICE industry in China. In the coming period, the MICE industry in China will continue to develop rapidly. For example, in Beijing and Shanghai, by 2015, the direct income of the MICE industry will reach 30 billion yuan and 20 billion yuan respectively, with an average annual growth rate of more than $15 \%$ [1]. The MICE industry is also one of the fastest growing industries in the world, particularly in the Asia Pacific region. Many countries have been engaged in constructing or renovating the infrastructure of MICE industry, also strengthening the policy and financial support
[2]. In the past 20 years, the economic impact assessment of large-scale activities has been the core and hotspot in the field of event activity research [3]. The exhibition activities are an important part of large-scale activities (or "an iconic event"), same as sports activities, become core elements of the implementation of the "event-induced" development strategy. Therefore, the research on the economic impact of the MICE industry can be cut from the perspective of economic impact research of large-scale activities, by learning its research ideas and methods.

At the very start, we used the tourism multiplier to roughly estimate the direct economic impact. But now, the Input-Output model (I-O), the Computable General Equilibrium (CGE) model and the regression model were widely used. The research methods for economic impact of event activities has been greatly improved. The I-O models have a broad application in the world, including the Regional Input-output Modeling System (RIMS) 
and the input-output model of the IMPLAN Group of Minnesota [4]. As for RIMS, it has an implied premise that the large-scale activities are limited to only one region. Obviously, this premise is theoretically untenable. Because the RIMS model just cover one region, so, it can not reflect the regional diffusion effects of large events, and will inevitably lead to problems such as inaccurate measurement and leakage. However, the Interregional Input-output Model (IRIO), designed to expand the basic inputoutput framework to capture transactions between industrial sectors in regions, can fully reflect the diffusion effect and overall effect of event activities. This is because the IRIO model overcomes the drawback of IO model that can only analyze the economic relationship between local production and demand in one industry and one region. It can systematically and comprehensively reflect the trade of products between different industries in different regions. It is an effective tool for regional economic analysis, such as the differences of regional economic, the interrelationships of interregional industry and the allocation of resources among different regions.

This paper used the table of China-IRIO 2002, which was constructed by CAS Research Center On Fictitious Economy and Data Science. We first merged 12 industrial sectors which are directly related to MICE industry, then constructed the influence power coefficient of intraregional and interregional to calculate the industry competitiveness and regional pulling capacity of MICE industry. Thus, we have a quantitative understanding of the diffusion path and regional differences of the economic impact of China's MICE industry. The economic impact of the MICE industry can only be achieved by project-driven. Without project, the final consumption cannot be transformed into consumption and the economic pulling effect of the MICE industry cannot be realized. Therefore, this study calculates the competitiveness and regional pull capability of China's MICE industry. So, taking the Canton Fair as a case, we estimate the economic pulling effect of the Canton Fair in 30 provinces and 12 related industries, from which we can actually know the economic pulling effect of the MICE industry.

China IRIO-2002 covers 30 provinces (excluding Tibet) and 60 industrial sectors (26 service sectors), which lays the foundation for the application research. It becomes an effective tool for economic analysis of MICE industry ${ }^{1}$. Since the China IRIO-2002 was just launched in 2012, it was first used in MICE research, so there are still many issues to be further explored.

\section{Literature Review}

\subsection{Foreign Literature Review}

In the past 20 years, the international large-scale activity economic impact assessment has made great progress in

\footnotetext{
1 Compared with the general input-output model (IO), the construction of interregional input-output model (IRIO) in China is relatively slow. The previous IRIO model was divided only by the region, including less industry sector, especially the lack of detailed division of services, making it impossible to use in the MICE.
}

research methods, such as sampling techniques, evaluation models and evaluation processes [5], especially the application of economic impact analysis method. The economic impact analysis method is based on the impact analysis of the economic growth paradigm [6]. This specific method is to calculate the indirect effect and the induced effect by using the I-O model or the CGE model after measuring the direct economic impact of tourists' consumption. Among them, the I-O model has been widely used. A group of scholars in the world have used the I-O model to analyze the economic impact of event activities [4], enriching the theoretical and empirical research results in this field.

Although the I-O model has the advantages of clear process and simple operation, there are obvious limitations. For example, the I-O model assumes that there is a linear relationship between the main economic variables, which cannot fully reflect the supply shortage or economies of scale, so it is possible to draw some misleading conclusions; The IO model neglects the constraints of supply, government budget, and trade payment balance in the economic process, which would easily lead to exaggeration of indirect benefit assessment; The I-O model unable to simulate all economic fluctuations, which increases the difficulty of separating local consumption. Although the government encouraging holding event activities, the scholars have controversial idea. Some scholars have questioned the existing research to evaluate the economic impact of event activities from a relatively large geographical area, overestimating economic benefits, underestimating opportunity costs and leakages [7, 8]. Meanwhile, in order to cater to the needs of politics, there is a tendency to overestimate the economic impact [9, 10]; Other scholars believe that the hosting events which costly and political overtones has some negative effects on the local economy, culture and environment [11], and the short-term economic benefits are not sufficient to explain all the problems [9].

Compared with sports activities, the study of the economic impact assessment of the MICE industry is weak. After the analysis of 115 exhibition academic papers in 1983-2003 years, only $8 \%$ were related to economic impact assessment [12]. The reason for this phenomenon is that the importance of the MICE has only recently been recognized; Second, it is difficult to track the consumption expenditure of exhibitors, visitors and participants; Third, the diversity of MICE has made it difficult to assess the economic impact; Fourth, most exhibitions are commercial activities, which bring difficulties in data acquisition [13]. The representative research in the world are the research on the economic diffusion effect of the 1985 Tsukuba Expo, which was completed by the Mitsubishi Research Institute (MRI) in Japan for more than five years. The study uses the IRIO model, covering 3 regions and 21 sectors. The conclusion of the study is that the direct cost of the Tsukuba Expo is 1.1579 trillion yen, which generates 2.3163 trillion yen of economic growth in Japan, roughly equivalent to $0.75 \%$ of Japan's GDP in $1985,1.9$ times the direct spending of the Tsukuba Expo [14]. 


\subsection{Domestic Literature Review}

The economic impact study of event activities in China is still in its infancy, the types of events involved are not rich enough, case studies and industry studies are lacking, and research methods are relatively simple. In China, the researches of scholars such as Dai Guangquan, Zhang Jingxiang, Zhang Yaxiong and Luo Qiuju are representative. For example, Dai Guangquan has pioneered the research field of domestic event tourism and event activities [5]. Zhang Jingxiang et al. analyzed the impact of regional big event marketing effects on urban growth [15]. All these researches are instructive.

As for the application of the I-O model, based on the survey of production input structure of 549 national key enterprises and enterprise groups, Zhang Yaxiong and Zhao Kun successfully developed IRIO models (including 17 industrial sectors and 3 regionals) and calculated the pulling effect of the Beijing Olympic Games investment on Beijing, surrounding areas and other regions of China. The research results show that the Olympic investment boosted the Beijing economy (2002-2007) by an average of about $2 \%$. At the same time, the Olympic investment has a strong diffusion effect, driving the economic contribution outside Beijing is greater than the contribution to Beijing [16]. This is by far the earliest research of exhibition activities in China using the IRIO model, its innovative value is impressive. Luo Qiuju et al. used questionnaires and in-depth interviews to obtain data on the direct economic impact of the Canton Fair. It is 5.526 billion yuan through the estimation of the consumption expenditure and structure of all participants in the 104th and 105th Canton Fairs. Using the I-O table of Guangdong Province (2002), she assessed the indirect economic impact of the Canton Fair on Guangzhou. The conclusion is that the direct and indirect effects of the Canton Fair in Guangzhou totaled 16.324 billion yuan, accounting for 1.98\% of Guangzhou's annual (2008) GDP. The indirect economic impact is 10.798 billion yuan, and the ratio of direct and indirect effects is 1:1.95 [4]. The study uses market research and regional I-O model to study exhibition consumption activities, which is one of the important achievements in the economic impact research of China's exhibition activities. Since the study is based on the Guangdong I-O table instead of the Guangzhou I-O table, the results should be understood as the indirect economic impact of the Canton Fair in Guangdong seems to be more reasonable, and the indirect economic impact of the Canton Fair is not covered. This research needs further explore.

Besides, Li Zhiling applied the direct influence power coefficient of the MICE industry (direct income/indirect income of the MICE industry) and indirect influence power coefficient (the total impact income/all income of the MICE industry on various sectors of the national economy), and constructed the influence power coefficient of the MICE industry. She assumes that the direct influence power coefficient is 9 , and the indirect influence power coefficient is 1.9, which leads to the conclusion that the Tsubo Expo will take action up to $1: 19$ [14]. Since this conclusion has not been empirically demonstrated, this result is yet to be verified.

At present, most of the research on the economic impact of China's MICE industry focus on the direct driving effect. Most of the methods used on-site investigation. For example, the direct driving coefficient of Beijing MICE industry is about $1: 9$, and the average driving coefficient of Shanghai MICE industry is $1: 8.4$ [1]. It is rare to use the IRIO model to measure the direct and induce economic impact of the MICE industry. The reason is that the MICE industry is not an independent industrial sector in the input-output table. How to define the relevant sectors of the MICE industry is a problem that needs to be solved first. Second, most of the industrial sectors related to the MICE industry are services. The service sector has not been detailed enough in the previous IRIO model, the information provided is insufficient. Third, the economic impact of the MICE industry is most prominent in the city. However, the geographical division of the IRIO model has not been refined to the provinces, making it limit to study and compare the industries between provinces.

Luckily, the above situation greatly improved since the emergence of China-IRIO-2002. China's IRIO model has been refined from large areas to inter-provincial areas on the regional scale. In the industrial sector, it has expanded from a dozen to 60, and the application fields have also expanded. Based on the China-IRIO-2002 model, scholars have make some research, such as Shimin Jun, Zhang Zhuoying etc, they make some research about the inter-provincial industry association, the echo effect and diffusion effect of the trade between provines, interregional economic linkages and demand induced effects. In addition, they also studied the application of interregional industrial structure isomorphism, water footprint, carbon footprint and provincial carbon emissions transfer based on the perspective of inter-industry trade and intra-industry trade [17]. These research cases provide useful reference for the application of the IRIO model in China's MICE industry.

\section{Methodology}

Since MICE industry involves a lot of industries and cover huge areas, meanwhile, lack of standard statistical norms and statistical calibers, it is difficult to determine the types of industries and the variables of economic impact. This study uses the input-output analysis to complete the empirical analysis by selecting appropriate input-output models, determining the measurement methods of the economic impact of the MICE industry, and matching the correspondence between the direct consumption of the MICE industry and the industrial sectors in the input-output model.

\subsection{Model Selection}

\subsubsection{Interregional Input-Output Model (IRIO)}

The interregional input-output model (IRIO) is a cross-regional input-output linkage model that uses commodity and labor to connect regional input-output models. Taken chronologically, the interregional input-output model (IRIO) structure was first described by Isard (1951) and 
elaborated in Isard et al. (1960). (This is often labeled the "Isard model".) Compared with the input-output model of a single region, the IRIO model can not only reflect the economic linkages between industries within the region, but also systematically reflect the economic linkages between different regions. Besides, it can compare the industrial structure and technology differences between different regions, analyze the interrelationship and impact of interregional industries, the rational allocation of resources between regions etc [17]. China IRIO-2002 is an interregional input-output model constructed under the framework of the interregional input-output model of Chenery-Moses, comprising 30 provinces and 60 industrial sectors. It is more suitable for research on exhibitions.

On the table, the China IRIO-2002 model decomposes the intermediate input and intermediate demand into 30 regions on the basis of the general I-O model, and each province is further decomposed into 60 sectors (including 26 service sectors); The final demand is also decomposed into 30 regions, and each regions is further decomposed into 4 parts, namely, household consumption, government consumption, fixed asset formation and inventory. The China IRIO-2002 model provides a wealth of information, making it an effective quantitative analysis tool for various regional economic relations research. Applying the IRIO model to research exhibition economy is worth exploring.

\subsubsection{The Intraregional and Interregional Influence Power Coefficient}

The influence power coefficient is critical when analyzing the industrial linkage by using I-O model. It denotes the total increase in output from the entire system of industries if there is an increase in the final demand for the products of one industry by one unit. The intraregional (interregional) influence power coefficient represents that the extent to which the demand for various sectors of the region (outside the region) is increased when an industry in a certain region increases one unit of final demand. The value of intraregional(interregional) influence power coefficient can be calculated the diffusion effect of this industry in the region (outside the region) relative to the average value [17]. The formula for calculating the intraregional and interregional influence power coefficient can be defined as:

$$
\begin{gathered}
I C_{j}^{S}=\frac{\frac{1}{m \times n} \sum_{R} \sum_{i} \sum_{i} b_{i j}^{R S} b_{j}^{R S}}{\sum_{j \text { int } e r}=\frac{\sum_{R(R \neq S)} \sum_{i} b_{i j}^{R S}}{\frac{1}{n} \sum_{R(R \neq S)} \sum_{i} \sum_{j} b_{i j}^{R S}}}
\end{gathered}
$$

$I C_{j}^{S}$ denotes the intraregional influence power coefficient of sector $\mathrm{j}$ in region $\mathrm{S}$. $I C_{j \text { inter }}^{S}$ denotes the interregional influence power coefficient of the sector $\mathrm{i}$ in region R. $b_{i j}^{R S}$ denotes the Leontief inverse coefficient of sector $\mathrm{i}$ in region $\mathrm{R}$ to sector $\mathrm{j}$ in region $\mathrm{S} . \mathrm{m}$ is the number of regions, $\mathrm{n}$ is the number of industrial sectors in each region. Where $m=30$ and $n=60$.

The larger the value of $I C_{j}^{S}$, the stronger pulling effect of $\mathrm{j}$ industry to the region. The larger the value of $I C_{j \text { inter }}^{S}$, the stronger pulling effect of $\mathrm{j}$ industry to the region outside. Whether $I C_{j}^{S}$ or $I C_{j \text { inter }}^{S}$, the value is greater than 1 (less than 1), indicating that the industry's diffusion effect to other sectors and other regions is higher than(lower than) the whole society average.

However, when calculating $b_{i j}^{R S}$, the impact of imports should be removed, because imports do not drive domestic inputs, and the formula is:

$$
\begin{gathered}
b_{i j}^{R S}=[I-(I-\hat{M}) A]^{-1} \\
\hat{m}_{i}^{R}=\frac{m_{i}^{R}}{\left(\sum_{S=1}^{30} \sum_{j=1}^{60} x_{i j}^{R S}+\sum_{S=1}^{30} \sum_{k=1}^{4} f_{i k}^{R S}\right)}
\end{gathered}
$$

$\mathrm{M}$ is the diagonal matrix of import coefficient, $\mathrm{A}$ is the direct input coefficient matrix, $\mathrm{I}$ is the identity matrix, $\mathrm{m}$ is the value of import, $\mathrm{f}$ is the final demand, $\mathrm{k}$ is the type of the final demand, $\mathrm{k}=4$.

\subsection{Definition and Measurement of Economic Impact of MICE Industry}

What industrial sectors the MICE industry involved, and how to measure their economic impact, there is no clear answer. This study defines the concept of the economic impact of MICE industry drawing on the latest international achievements on the economic impact of event activities. Solberg, et al. argue that the economic impact of event activity refers to the "new money injected into an economy by visitors" [18]. In another word, the injection of new money triggered by the event activities, participated in the economic cycle of the region, which changes the economic aggregate in region. We can call the degree of change as the economic impact of event activities. This definition is generally accepted.

Janezzko et al. used a ripple in a pond as a metaphor to explain the direct, indirect, and induced economic impacts of event activities. In first round, "visitors" visited the event venues due to the event activities, resulting in direct consumer spending ---- "in-scope consumption", also known as "direct economic impact"; In second round, the injection of this new money caused a new round of consumer spending ---"indirect economic impact"; In third round, second round of consumer spending will trigger a third round of consumer spending ---- "induce economic impact". Among them, the first round of consumer spending is also called the initial economic impact, and the indirect economic impacts and 
induce economic impacts after the second round are collectively referred to as secondary economic impacts [4].

The economic impact of the MICE industry studied in this paper refers to the changes in the regional economic aggregate and structure due to the holding of the exhibition activities. This change can be examined through three levels: direct, indirect and induce economic impact. Among them, the direct economic impact of the MICE industry refers to the consumer expenditure of participants in the exhibition activities (such as exhibitors, visitors, organizers and media representatives), which is mainly embodied in the direct consumption of the exhibition host city, such as lodging, catering, urban transportation, shopping, entertainment, etc. The indirect and induce economic impact of the MICE industry refers to the diffusion effect of the direct consumption expenditure of participants in the exhibition activities at different regional through industrial linkage, which can be transmitted to the whole country, such as printing, electricity and water, construction, information transmission and computer services, etc. In order to compare with Luo Qiuju's research in 2011, this study combines the indirect and induce economic impact to represent the indirect economic impact of the MICE industry. It has the same meaning of secondary economic impact of Janezko et al.

By means of field sample survey, the average cost of each participant in the exhibition can be estimated. This is the direct economic impact of MICE industry. But for indirect economic impact, the I-O model play an important role. In this study, the China IRIO-2002 model was used to measure the indirect economic impact. The formula is:

$$
\begin{gathered}
X=B Y \\
B=[I-(I-\hat{M}) A]^{-1}-I
\end{gathered}
$$

$\mathrm{X}$ indicates indirect economic impact matrix of MICE industry, $\mathrm{B}$ indicates the total input coefficient matrix, $\mathrm{Y}$ indicates direct economic impact matrix of MICE industry ${ }^{2}$.

\subsection{Matching I-O Sectors with Direct Expenditures Related to $\mathrm{MICE}$}

Through the total input coefficient, the direct economic impact will be enlarged into the indirect economic impact of the exhibition. It is necessary to match the expenditure items of attendants with industrial sectors of the I-O model. The exhibition activities involve multiple subjects, such as exhibitions (corporate or individual), visitors (professional visitors and general visitors), organizers and trading groups. The total direct consumption expenditures involved in these entities are the direct economic impact of the exhibition. The direct consumption items of the entities of the exhibition are quite extensive, generally including booth leasing, construction, accommodation, catering, shopping, entertainment, tourism, transportation, communication, advertising, warehousing, water and electricity, printing,

2 The direct economic impact of the exhibition can be obtained by investigating the specific expenditures of each project. equipment leasing, engineering and maintenance expenses, temporary labor, parking, registration, hospitality and business expenses etc. These expenditure items of attendants can be matched with the 12 industry sectors in China IRIO-2002 (Table 1). After the merging of 12 industrial sectors, an independent industry type — the MICE industry, was created. To this end, it is possible to carry out the I-O analyze of the MICE industry.

Table 1. Expenditure items of the attendants in corresponding sectors in China IRIO-2002.

\begin{tabular}{lll}
\hline No & \multicolumn{1}{c}{ China IRIO-2002 sectors } & Expenditure items of the attendants \\
\hline 1 & $\begin{array}{l}\text { Paper, printing and stationary } \\
\text { related, toys products }\end{array}$ & printing fee \\
2 & $\begin{array}{l}\text { Electricity, steam and hot } \\
\text { water production and supply }\end{array}$ & electricity and water \\
3 & $\begin{array}{l}\text { Construction } \\
\text { construction cost }\end{array}$ \\
4 & $\begin{array}{l}\text { Urban public transport } \\
\text { services of passengers }\end{array}$ & local transportation cost \\
5 & $\begin{array}{l}\text { Storage and warehousing } \\
\text { Telecommunication and }\end{array}$ & storage fee \\
6 & $\begin{array}{l}\text { Computer services } \\
\text { Wholesale and retail trade }\end{array}$ & post, internet and communication fee \\
7 & $\begin{array}{l}\text { services } \\
\text { Accommodation and food } \\
8\end{array}$ & $\begin{array}{l}\text { perving services } \\
\text { room and board cost }\end{array}$ \\
9 & $\begin{array}{l}\text { Rental and business services } \\
\text { Travel agency, tour operator }\end{array}$ & $\begin{array}{l}\text { exhibition fee, advertisement, } \\
\text { marketing cost, reception cost etc. }\end{array}$ \\
10 & $\begin{array}{l}\text { and tourist guide services } \\
\text { travel cost }\end{array}$ \\
11 & $\begin{array}{l}\text { Social services and Resident } \\
\text { services }\end{array}$ & $\begin{array}{l}\text { Cultural, media } \\
\text { reparation spending, registration fee, } \\
\text { parking fee, casual laborer fee }\end{array}$ \\
\hline
\end{tabular}

\section{Discussion}

\subsection{The Influence Power of China's MICE Industry}

The indirect economic impact of China's MICE industry can be examined through the intraregional influence power coefficient $\left(M I C_{j}^{S}\right)$ and the interregional influence power coefficient ( $M I C_{j \text { inter }}^{S}$ ) of the MICE industry. Merging the 12 industrial sectors of the China IRIO-2002 model, $M I C_{j}^{S}$ and $M I C_{j \text { inter }}^{S}$ were calculated (Table 2). Table 2 shows the full picture of $M I C_{j}^{S}$ and $M I C_{j \text { inter }}^{S}$ from the absolute value (different area) and the relative value (compared with different industries in the same area, expressed by the percentile of the exhibition industry in all industries).

\footnotetext{
3 The scope of tourism is taken from China IRIO-2002, which is consistent with the scope of "tourism" (code 74110) in the "China Input-Output Table 2002" (page 445), which means "providing business for all sectors of society, providing travel service for group tours and individual, including consultation, travel planning and construction, scheduling, tour guides, accommodation and transportation services to customers," May not be exactly the same as the concept of tourism in other disciplines. Same as below.
} 
Table 2. Influence power coefficient of MICE in China and the percentile in all industries.

\begin{tabular}{|c|c|c|c|c|c|c|c|c|}
\hline \multirow{2}{*}{$\frac{\text { No. }}{1}$} & \multicolumn{2}{|l|}{$M I C_{j}^{S}$} & \multicolumn{2}{|c|}{ Percent of $M I C_{j}^{S}$ in all sectors } & \multicolumn{2}{|l|}{$M I C_{j \text { int er }}^{S}$} & \multicolumn{2}{|c|}{ Percent of $M I C_{j \text { inter }}^{S}$ in all sectors } \\
\hline & Henan & 1.3812 & Jiangsu & $12 \%$ & Guangdong & 1.1835 & Guangdong & $10 \%$ \\
\hline 2 & Sichuan & 1.3217 & Guangdong & $22 \%$ & Shanghai & 1.1168 & Hubei & $10 \%$ \\
\hline 3 & Gansu & 1.2755 & Zhejiang & $23 \%$ & Jiangsu & 1.1164 & Zhejiang & $12 \%$ \\
\hline 4 & Shanxi & 1.2702 & Hainan & $23 \%$ & Zhejiang & 1.1157 & Jiangsu & $22 \%$ \\
\hline 5 & Qinghai & 1.2275 & Shanghai & $25 \%$ & Xinjiang & 1.1087 & Henan & $23 \%$ \\
\hline 6 & Hubei & 1.2264 & Henan & $28 \%$ & Shanxi & 1.1064 & Inner Mongolia & $25 \%$ \\
\hline 7 & Shaanxi & 1.2262 & Sichuan & $28 \%$ & Inner Mongolia & 1.0843 & Fujian & $27 \%$ \\
\hline 8 & Xinjiang & 1.2016 & Jilin & $30 \%$ & Jiangxi & 1.0798 & Shandong & $27 \%$ \\
\hline 9 & Ningxia & 1.1917 & Shandong & $30 \%$ & Hunan & 1.0795 & Hebei & $28 \%$ \\
\hline 10 & Chongqing & 1.1776 & Hubei & $30 \%$ & Anhui & 1.0781 & Hunan & $28 \%$ \\
\hline 11 & Hebei & 1.1343 & Inner Mongolia & $33 \%$ & Gansu & 1.0752 & Liaoning & $32 \%$ \\
\hline 12 & Hunan & 1.1287 & Fujian & $33 \%$ & Hebei & 1.0743 & Jilin & $33 \%$ \\
\hline 13 & Fujian & 1.1147 & Jiangxi & $33 \%$ & Fujian & 1.0710 & Shanghai & $33 \%$ \\
\hline 14 & Inner Mongolia & 1.0925 & Anhui & $37 \%$ & Henan & 1.0686 & Anhui & $33 \%$ \\
\hline 15 & Shandong & 1.0701 & Hunan & $37 \%$ & Guangxi & 1.0639 & Jiangxi & $33 \%$ \\
\hline 16 & Jiangxi & 1.0657 & Chongqing & $37 \%$ & Chongqing & 1.0595 & Xinjiang & $33 \%$ \\
\hline 17 & Jiangsu & 1.0451 & Hebei & $38 \%$ & Ningxia & 1.0580 & Shanxi & $35 \%$ \\
\hline 18 & Heilongjiang & 1.0407 & Liaoning & $38 \%$ & Hubei & 1.0556 & Chongqing & $35 \%$ \\
\hline 19 & Hainan & 1.0373 & Xinjiang & $42 \%$ & Yunnan & 1.0491 & Guizhou & $40 \%$ \\
\hline 20 & Jilin & 1.0265 & Yunnan & $43 \%$ & Hainan & 1.0476 & Gansu & $40 \%$ \\
\hline 21 & Guizhou & 1.0050 & Shanxi & $45 \%$ & Beijing & 1.0465 & Hainan & $43 \%$ \\
\hline 22 & Anhui & 0.9817 & Gansu & $47 \%$ & Guizhou & 1.0435 & Guangxi & $48 \%$ \\
\hline 23 & Yunnan & 0.9555 & Ningxia & $50 \%$ & Liaoning & 1.0392 & Sichuan & $52 \%$ \\
\hline 24 & Beijing & 0.9496 & Shaanxi & $52 \%$ & Qinghai & 1.0322 & Shaanxi & $53 \%$ \\
\hline 25 & Zhejiang & 0.9439 & Guizhou & $53 \%$ & Jilin & 1.0288 & Ningxia & $55 \%$ \\
\hline 26 & Guangxi & 0.8830 & Beijing & $57 \%$ & Heilongiiang & 1.0249 & Heilongjiang & $57 \%$ \\
\hline 27 & Tianjin & 0.8361 & Heilongjiang & $58 \%$ & Shaanxi & 1.0082 & Yunnan & $57 \%$ \\
\hline 28 & Liaoning & 0.7745 & Guangxi & $60 \%$ & Shandong & 1.0047 & Beijing & $65 \%$ \\
\hline 29 & Guangdong & 0.7287 & Tianjin & $67 \%$ & Sichuan & 1.0044 & Tianjin & $65 \%$ \\
\hline 30 & Shanghai & 0.6824 & Qinghai & $80 \%$ & Tianjin & 0.9926 & Qinghai & $82 \%$ \\
\hline
\end{tabular}

\subsubsection{Intraregional Influence Power of MICE Industry}

The average value of $M I C_{j}^{S}$ in China is 1.0665 , which is higher than the average level of the whole society. It shows that the MICE industry's pulling effect on the national economy exceeds the average level of all industries. Among them, the value of $M I C_{j}^{S}$ among 21 regions is greater than 1. Henan, Sichuan, Gansu, Shanxi and Qinghai, which from the Midwest, are in the top five. Guangxi, Tianjin, Liaoning, Guangdong and Shanghai ranked in the bottom five, mainly in the East Coast. In terms of absolute value, the value of $M I C_{j}^{S}$ overall shows the Midwest are larger than the East Coast. Why? It is the level of regional economic development and the foundation of the development of the MICE industry that counts. Generally speaking, the economic development level in the Midwest is relatively low, and the construction of exhibition infrastructure is relatively lagging. The development of the MICE industry requires more investment in venues and other supporting facilities. Therefore, although in the same input structure, the MICE industry in the Midwest can bring more investment to other sectors than the East Coast, resulting in greater total output effects ${ }^{4}$. In this paper, the

4 In the article $<$ Revaluating Traditional Formula of Influence Power Coefficient $>$, Shen Lisheng believes that the criterion of total output as the influence power in not reasonable, but the added value should be used as criterion for the influence power. According to the total output, the influence power of China's manufacturing calculation of $M I C_{j}^{S}$ is based on the total output, not added value, so, the regional influence power of MICE industry in the Midwest is larger than that of the East Coast.

In terms of relative value, the regional gradient of $M I C_{j}^{S}$ in all industries is not obvious. The average value of $M I C_{j}^{S}$ in all industries is $39.7 \%$, of which Jiangsu, Guangdong, Zhejiang, Hainan and Shanghai rank in the top five, Beijing, Heilongjiang, Guangxi, Tianjin and Qinghai rank in the last five. The value of $M I C_{j}^{S}$ in all industries depends on the state of the regional industrial structure and the number of industrial sectors with specialization. In the production process, because of the large consumption of products from other sectors, the manufacturing industry has a larger driving effect on other sectors. The research of Shen Lisheng shows that the manufacturing industry's pulling power on total output is higher than that of service industry ${ }^{5}$. Shi Minjun, Zhang Zhuoying, whom do some research of industry association in

industry is greater than that of the service industry; the impact of China's service industry is greater than that of the manufacturing industry by the value-added. For details, see "Quantitative Economics and Technology Research", No. 2, 2010.

5 Another study of the author in cross-country comparative on industrial pull capacity, indicating that the manufacturing industry in China, South Korea, Japan, Germany, Britain, France and the United States has a higher pulling coefficient for total output than the service industry. In 14 manufacturing sectors and 14 service sectors, the pull factor is greater than 1 . The manufacturing sector is $12-14$, while the service sector is $2-9$. The relevant results are being sorted out. 
region of China, pointed out that the manufacturing sector has the strong economic pulling power among all industries. For example, automobile manufacturing industry (1.26), money metal products industry (1.25), motor and home appliance manufacturing (1.24), etc. The influence of modern service industries such as finance and insurance, real estate, leasing and business services in Beijing and Shanghai is not as high as the national average. The influence power coefficient of that industries is $0.86,0.98$ and 0.74 respectively. Shanghai is 0.74 , 0.67 and 0.91 respectively [17]. In addition, if the manufacturing industry in one region has a higher degree of specialization, its influence will be greater. As one of the modern service industries, the performance of the MICE industry in terms of industrial influence should conform to the general characteristics of the service industry. So, while the manufacturing industry dominate the industrial structure in the region, the value of $M I C_{j}^{S}$ is generally relatively backward, but service industry dominates, the value of $M I C_{j}^{S}$ is generally relative to the top position. If the level of manufacturing specialization in the region is high, the value of $M I C_{j}^{S}$ is generally relative to the lower position; if the level of manufacturing specialization is not high, the value of $M I C_{j}^{S}$ is generally relative to the top position. For the above reasons, the developed regions such as Jiangsu, Guangdong, Zhejiang and Shanghai (the top 25\%) rank first, while the underdeveloped regions such as Heilongjiang, Guangxi and Qinghai are in the second place (60\% to $80 \%)$. Combined with the scale of the industry, the rank of $M I C_{j}^{S}$ more realistically reflects the degree of development of China's MICE industry. Obviously, the development level of developed regions is higher than that of relatively underdeveloped regions.

\subsubsection{Interregional Influence Power of MICE Industry}

The average value of $M I C_{j \text { inter }}^{S}$ in China is 1.0639, which is higher than the average level of the whole society. The value of $M I C_{j \text { inter }}^{S}$ in 29 provinces is greater than 1, and almost all provinces have the diffusion effect, with Guangdong, Shanghai, Jiangsu, Zhejiang and Xinjiang ranking in the top five, Heilongjiang, Shaanxi, Shandong, Sichuan and Tianjin ranked in the bottom five. The average value of $M I C_{j \text { inter }}^{S}$ in China in all industries is $37.87 \%$, of which Guangdong, Hubei, Zhejiang, Jiangsu and Henan rank in the top five, and Heilongjiang, Yunnan, Beijing, Tianjin and Qinghai are in the bottom five. In terms of absolute value, the value of $M I C_{j \text { inter }}^{S}$ in China generally shows that the East Coast are bigger than the Midwest; In terms of relative value, the regional gradient of $M I C_{j \text { inter }}^{S}$ in China in all industries is not obvious. The existence of the above characteristics is closely related to the degree of regional economic openness. This is because the interregional influence power is the same as the intraregional influence power, but the interregional influence power removes the pulling effect on the local region and focuses on the influence on regions outside. If the interregional influence power is large, it indicates that the region is highly marketized and closely related to the industries of other regions. In another word, the value of $M I C_{j \text { inter }}^{S}$ in a region with higher degree of marketization is larger. Typically, the characteristics of the open economy in the East Coast are more obvious and the degree of marketization is also high, resulting greater economic linkage than that in the Midwest. To this end, the mutual driving effect of the MICE industry in the East Coast is greater than that in the Midwest. Whether it's an absolute value or a relative value, the value of $M I C_{j \text { inter }}^{S}$ in Guangdong, Zhejiang, Jiangsu are all in the forefront. Zhang Yaxiong and Zhao Kun's research also shows that the spillover effect of Olympic investment on the region outside Beijing is more than the economic contribution to Beijing [16].

\subsection{The Economic Pulling Effect of Canton Fair in China's MICE Industry}

The research of Luo Qiuju shows that the direct economic impact of the $104^{\text {th }}$ Canton Fair is 5.526 billion yuan. In this paper, we use this data and the China IRIO-2002 model, to calculate the indirect economic impact of the 104th Canton Fair in 30 regions (Table 3, Table 4). The results are mainly as follows:

Table 3. Indirect economic impact for 30 provinces of the 104th Canton Fair (10,000 yuan).

\begin{tabular}{|c|c|c|c|c|c|c|c|}
\hline No. & Regions & Output of 12 sectors & Percent & No. & Regions & Output of 12 sectors & Percent \\
\hline 1 & Guangdong & 569901.81 & $35.09 \%$ & 16 & Liaoning & 22891.85 & $1.41 \%$ \\
\hline 2 & Hunan & 110692.79 & $6.81 \%$ & 17 & Heilongjiang & 21018.46 & $1.29 \%$ \\
\hline 3 & Shandong & 108559.51 & $6.68 \%$ & 18 & Beijing & 19920.74 & $1.23 \%$ \\
\hline 4 & Fujian & 108139.59 & $6.66 \%$ & 19 & Anhui & 19913.60 & $1.23 \%$ \\
\hline 5 & Jiangsu & 105149.64 & $6.47 \%$ & 20 & Jiangxi & 18288.87 & $1.13 \%$ \\
\hline 6 & Zhejiang & 77199.49 & $4.75 \%$ & 21 & Xinjiang & 16548.72 & $1.02 \%$ \\
\hline 7 & Hubei & 62925.67 & $3.87 \%$ & 22 & Yunnan & 15368.58 & $0.95 \%$ \\
\hline 9 & Sichuan & 46388.12 & $2.86 \%$ & 24 & Shaanxi & 13726.86 & $0.85 \%$ \\
\hline 10 & Henan & 34255.51 & $2.11 \%$ & 25 & Shanxi & 11868.11 & $0.73 \%$ \\
\hline 11 & Chongqing & 31322.16 & $1.93 \%$ & 26 & Guizhou & 10279.47 & $0.63 \%$ \\
\hline 12 & Guangxi & 31158.02 & $1.92 \%$ & 27 & Tianjin & 9551.14 & $0.59 \%$ \\
\hline 13 & Hebei & 30889.51 & $1.90 \%$ & 28 & Gansu & 6738.68 & $0.41 \%$ \\
\hline 14 & Hainan & 28488.22 & $1.75 \%$ & 29 & Qinghai & 2235.06 & $0.14 \%$ \\
\hline 15 & Jilin & 23325.58 & $1.44 \%$ & 30 & Ningxia & 1351.37 & $0.08 \%$ \\
\hline
\end{tabular}


Table 4. Indirect economic impact for 12 industry sectors of the 104th Canton Fair(10,000 yuan).

\begin{tabular}{|c|c|c|c|}
\hline No & 12 sectors & Total output of 30 provinces & Percent \\
\hline 1 & Wholesale and retail trade services & 316010.63 & $19 \%$ \\
\hline 2 & Electricity, steam and hot water production and supply & 299323.44 & $18 \%$ \\
\hline 3 & Paper, printing and stationary related, toys products & 259584.80 & $16 \%$ \\
\hline 4 & Accommodation and food serving services & 196712.76 & $12 \%$ \\
\hline 5 & Telecommunication and computer services & 186571.44 & $11 \%$ \\
\hline 6 & Rental and business services & 126817.39 & $8 \%$ \\
\hline 7 & Cultural, media communication, sporting and recreational services & 60736.36 & $4 \%$ \\
\hline 9 & Social services and resident services & 41921.38 & $3 \%$ \\
\hline 10 & Travel agency, tour operator and tourist guide services & 37914.70 & $2 \%$ \\
\hline 11 & Urban public transport services of passengers & 21769.07 & $1 \%$ \\
\hline 12 & Storage and warehousing & 19451.11 & $1 \%$ \\
\hline Total & & 1624284.60 & $100 \%$ \\
\hline
\end{tabular}

(1) The indirect economic impact of the 104th Canton Fair was about 16.243 billion yuan, and the ratio of direct to indirect effects was 1:2.94. In terms of regions, the pulling effect of $2 / 3$ provinces in the country is greater than 1\%, of which Guangdong is 5.699 billion yuan, the highest proportion, $35.09 \%$, followed by Hunan, Shandong, Fujian and Jiangsu, accounting between $6 \%$ to $7 \%$. The total of these five provinces is $61.72 \%$. Guangdong Province has the largest indirect economic impact in the Canton Fair, followed by the neighboring Province, Hunan and Fujian Province. And the coastal provinces such as Shandong, Jiangsu, Zhejiang, Shanghai, Hubei, Sichuan, and Henan are significantly affected. It conforms to the general law of regional economic operation in China and reflects the basic status of the regional influence of the Canton Fair.

(2) Among the 12 industrial sectors driven by the MICE industry, "wholesale and retail trade services", "Electricity, steam and hot water production and supply", "Paper, printing and stationary related, toys products", "Accommodation and food serving services", "Telecommunication and computer services" were most affected, accounting for 77\%. Among them, "Wholesale and retail trade services", "Electricity, steam and hot water production and supply", "Paper, printing and stationary related, toys products" accounted for 19\%, $18 \%$, and $16 \%$ respectively, while "Urban public transport services of passengers", "Storage and warehousing" accounted for only $1 \%$. The above results conform to the nature of industry and the law of diffusion, is reasonable.

The research of Luo Qiuju shows that the indirect economic impact of the 104th Canton Fair in Guangzhou is 10.798 billion yuan [4]. We think that this estimate is too large. First, the study was based on the Guangdong province input-output table (2002), the results of which should be the impact on Guangdong province, not Guangzhou; Second, the effect of imports is not removed, resulting in a large direct input coefficient and technical overestimation. This paper is based on China IRIO-2002. The calculation results cover 30 provinces in China, and the effect of imports was removed, which can fully reflect the indirect economic impact of the Canton Fair.

\section{Conclusion}

Based on the China IRIO-2002 model, this study draws the following conclusions:

(1) The influence power of China's MICE industry is generally higher than the average level. With a strong pulling power on the national economy and diffusion effect for almost all provinces, it has certain comparative advantages in terms of intraregional influence power and interregional influence power.

(2) From the perspective of absolute value, the influence power of MICE industry in China has significant regional differences. At the level of total output, the influence power of MICE industry of the Midwest is greater than in the East Coast in intraregional, while the East Coast greater than the Midwest in interregional. In terms of relative value, whether it is $M I C_{j}^{S}$ or $M I C_{j \text { inter }}^{S}$, the regional gradients in all industries are not obvious. According to the mechanism, the position of the MICE industry in all industries can better reflect the true level of development of a regional MICE industry. The existence of the above phenomenon is closely related to factors such as the level of regional economic development, the foundation of the development of the MICE industry, the regional industrial structure, the regional specialization level of the industry and the degree of regional economic openness.

(3) The intraregional and interregional influence power of MICE industry in China are in the top $40 \%$ of the total. It shows that a lot of provinces have the potential to further enhance the intraregional and interregional influence power of the MICE industry. There is still a certain upside for the development of MICE industry in China.

(4) Case studies show that the indirect economic impact of the 104th Canton Fair is about 16.243 billion yuan (Guangdong has the highest proportion, at 35.09\%), and the ratio of direct and indirect effects is 1:2.94; "wholesale and retail trade services", "Electricity, steam and hot water production and supply", "Paper, printing and stationary related, toys products", "Accommodation 
and food serving services", "Telecommunication and computer services" were most affected, accounting for $77 \%$.

\section{References}

[1] Li Tiecheng, Liu Li. The new features and countermeasures of MICE in China [J]. Economic Review, 2012, (7):80-83.

[2] Mistilis N, Dwyer L. Tourism gateways and regional economies: The distributional impacts of MICE [J]. International Journal of Tourism Research, 1999, 1(6):441-257.

[3] Dwyer L, Forsyth P, Spurr R. Estimating the impacts of special events on an economy [J]. Journal of Travel Research, 2005, 43(4): 351-359.

[4] Luo Qiuju, Pang Jiawen, Jin Wenmin. An empirical study on the economic impact of the events with input-output model: A case study of Canton Fair, China [J]. Acta Geographica Sinica, 2011, (4):487-503.

[5] Dai Guangquan, Bao Jigang. Quantitative effects assessments of Expo'99 Kunming: Model of background trend line [J]. Scientia Geographica Sinica, 2007, 27(3):426-432.

[6] Burgan B, Mules T. Reconciling cost-benefit and economic impact assessment for event tourism [J]. Tourism Economics, 2001, 7(4):321-330.

[7] Daniels M J. Central place theory and sport tourism impacts [J]. Annals of Tourism Research, 2007, 34(2):332-347.

[8] Hodur N M, Leistritz F L. Estimating the economic impact of event tourism: A review of issues and methods [J]. Journal of Convention and Event Tourism, 2006, 8(4):63-79.

[9] Jones C. Mega-events and host-region impacts: Determining the true worth of the 1999 Rugby World Cup [J]. International Journal of Tourism Research, 2001, 3(3):241-251.
[10] Sack A L, Johnson A T. Politics, economic development, and the Volvo International Tennis Tournament [J]. Journal of Sport Management, 1996, 10(1):1-14.

[11] Cornelissen S. Sport mega-events in Africa: Processes, impacts and prospects $[\mathrm{J}]$. Tourism and Hospitality Planning \& Development, 2004, 1(1):39-55.

[12] Yoo J J, Weber K. Progress in convention tourism research [J]. Journal of Hospitality \& Tourism Research, 2005, 29(2): 194-222.

[13] Kim S S, Chon K, Chung K Y. Convention industry in South Korea: An economic impact analysis [J]. Tourism Management, 2003, 24(5): 533-541.

[14] Li Zhiling. The driving effects of convention and exhibition industry [J]. Economic Management, 2011, (6):125-131.

[15] Zhang Jingxiang, Yin Jie, Luo Zhendong. Analysis of urban growth manchine based on great event marketing: Case study of Nanjing New Olympic City [J]. Economic Geography, 2007, 27(3):452-457.

[16] Zhang Yaxiong, Zhao Kun. The impact of Beijing Olympic-related investments on regional economic growth of China: interregional input-output approach [J]. Economic Research Journal, 2008, (3): 4-15.

[17] Shi Minjun, Zhang Zhuoying, et al. China Interregional Input-output Model and Interregional Economic Ties [M]. Beijing: Beijing Science Press, 2012.20; 59-60;61.

[18] Solberg H A, Andersson T D, Shibli S. An exploration of the direct economic impacts from business travelers at world championships [J]. Event Management, 2002, 7(3):151-164.

[19] Crompton J L, Mckay S L. Measuring the economic impact of festivals and events: Some myths, misapplications, and ethical dilemmas [J]. Festival Management and Event Tourism, 1994, 2(1):33-43 